\title{
ANALYSIS OF ECONOMIC, LEGAL AND DEMOGRAPHIC CONDITIONS FOR CARE SERVICES DEVELOPMENT IN THE UKRAINIAN RURAL AREAS
}

\author{
Nadiya Khorunzhak ${ }^{3}$, Doctor of Science in Economics, Professor; Nataliia Semenyshena ${ }^{1,2}$, \\ $\mathrm{PhD}$ in Economics, Assoc. Professor; Marianna Koshchynets ${ }^{4}$, PhD in Economics, Assistant \\ Professor and Svitlana Sysiuk, PhD in Economics, Assoc. Professor \\ ${ }_{1,4}$ Ternopil National Economic University, Ternopil, Ukraine; ${ }^{2}$ State Agrarian and Engineering University in \\ Podilya, Kamianets-Podilskyi, Ukraine; ${ }^{3}$ National Academy of Internal Affairs, Kyiv, Ukraine
}

\begin{abstract}
The study aims at identifying the initial conditions/prerequisites for the development of a care system for people who need it (the elderly, the disabled etc.). Based on the assessment of world experience, a conclusion was drawn on the effectiveness of the so-called "green care". To ascertain the necessity in the development of such a type of activity, the structure of the permanent rural population was analysed, according to which the expediency of developing care facilities and services was justified. On the basis of the survey results with respondents of different age groups and status (heads of united territorial communities, youth aged 15-23, and older people over the age of 80 years), the difference in the choice of priorities for spending funds in different directions was set. Young people and the elderly consider the social component to be a priority, while the heads of the united territorial communities give priority to the road repair. On the basis of the analysis of the population dynamics indicators and the number of employed rural population, the reserve of people of working age was revealed, which, after completing relevant courses and obtaining the necessary qualifications, may be attracted into care activities. In the course of the research, the ways of improving the regulatory and legal framework of Ukraine, governing the provision of care services and their accounting systems, were substantiated.
\end{abstract}

Key words: care services, problems, demography, standardization, development, improvement, international experience.

JEL code: J 110, J 210.

\section{Introduction}

In world practice, there are many positive examples of a comprehensive solution to the problem of unemployment and increase in the level of social protection of the population, especially in terms of meeting the demand for care services for the elderly and the disabled. A number of scientific studies contain suggestions on innovative approaches to solving the problem of social assistance and rehabilitation.

In particular, Ryszard Kaminski, Tomasz Marcysiak and Piotr Prus (2018) substantiate the feasibility and benefits of green Care farms in Poland for the arrangement of care of elderly and disabled people. The authors point to the positive psychological and physiological influence of this kind of activity on the general well-being and the state of health of people, who were cared for. Also, scientists produce compelling statistics. These indicators characterize the initial conditions of Poland and other countries and indicate the negative form of the demographic pyramid. The latter, in turn, forms the economic and social challenges that require resolution (social protection of the disabled etc.).

A number of other problems, associated with the negative demographic dynamics and ageing of the nation, are to be addressed. As various scientists note, the following problems should be highlighted:

- the decline in the number of working-age population (Bookman and Kimbrel 2011; Borsch-Supan, 2003);

- the increase of the pension load and the need for medical care (Arai et al., 2012; Mazura, 2012);

- the need to develop a network of institutions for the care of elderly and disabled people, which requires significant financial investments (Mazura, 2012);

\footnotetext{
${ }^{1}$ Corresponding author: Nataliia Semenyshena:,+380 975103680, natviksem@gmail.com
} 
- the growing need for social workers and enhancing requirements for the level of their competencies and functional responsibilities (Semygina, Gryga, 2004) etc.

In many countries, the issue of improving the quality of life of the elderly and disabled people is being addressed not only through the functioning of special state care institutions. The experience of L'agricoltura socjale (Italy) (Giare, 2009), Buurtzorg (Netherlands) (Schuringa, 2018), the new organization of home care for the sick, and others can be of great value.

In Ukraine, such areas are being explored in that context that only the territorial community and its executive authorities and self-government should determine the direction of arranging in the village an optimal living environment focused on the social interest of all residents, creating in rural settlements adequate working and living conditions (Chopenko, 2014). However, in such matters, one and the same problem remains unsolved in any country. It consists of solving financial (resource) and ethical issues. In a number of developed foreign countries, both problems are being solved by implementing various state programs and, accordingly, controlled by state institutions. In Ukraine, these problems cause concern and tough discussions at various levels of both, the authorities and the media, and still remain unsolved due to the lack of a state Strategy. It is partially embodied in the process of reforming the pension system. At the same time, the general reaction of many elderly people to this realization, as well as other segments of the population, is characterized by negative reviews. In conjunction with health care reform, budget deficits and migration trends with the large part of the young population being orientated towards education and labour abroad, the problem of social protection and ensuring appropriate living conditions for the elderly and the disabled is being exacerbated. In such circumstances, the Polish experience of organizing the so-called "green care", as well as the experience of other countries, would be useful for Ukraine.

Thus, the aim of the study was to identify the initial conditions for the development of a care system for people who need it (the elderly, the disabled etc.). In the course of the study, an analysis of statistical indicators was used to justify the need for the development of a care system. It allowed revealing the tendency to the ageing of the Ukrainians (negative pyramid). The analysis was also used to identify the possibility of providing care activity with a workforce. Using a survey of young people (150 young people aged between 16 and 23 were surveyed), people aged over 80 years and comparing its results to a survey published in the Report on the research findings on the progress in territorial communities unification (Zvit pro rezultaty doslidzhennia uspishnosti obiednannia terytorialnykh hromad, 2017) (52 heads of united territorial communities were surveyed), an assessment of views on the priority of the task of expanding and developing a network of care institutions and such a type of activity was carried out. In the group, where $63 \%$ of students, considere support for business development, education and science, health care and social protection (including the development of military rehabilitation centres and care centres for the elderly and disabled) to be the priority areas of spending, more than $67 \%$ of the young people were born in rural areas. Surveys of 150 people aged over 80 years and living in rural areas showed that they had problems with care and a desired to have nurses.

The assessment of the current legal norms on social protection of the population with a view to their effectiveness has led to the conclusion that it is advisable to further standardize not only the quality of services but also their accounting and calculation systems. 


\section{Research results and discussion Initial conditions for the development of the system of care for the elderly and disabled in Ukraine}

Features and conditions of the development of care systems for the elderly, including the use of elements related to nature (occupational therapy and therapy with animals etc.), are widely represented in foreign and partially domestic publications (Kaminski, Marcysiak, Prus, 2018; Bookman, Kimbrel 2011; Schuringa, 2018; Artz, Davis, 2017; Mazura, 2012; Kanyuk, 2015; Davydyuk, 2016; et al.). The authors draw attention to the regulatory and economic factors of the development of this type of activity, as well as its results.

For Ukraine, this aspect is characterized by a low level of interest of private investors in the implementation of care activities. Therefore, it should be noted that private nursing homes, nowadays, are practically absent. But, in Ukraine, there are 286 boarding schools for adults of state and communal ownership, 238 of which are for the elderly and 48 for children and young people. Of the total number of boarding houses for adults: 62 - for the elderly and disabled; 28 - boarding houses for the war and labour veterans; 145 - neuropsychiatric boarding houses; 3 - special boarding houses. In addition, there are also territorial centres of social services that provide services at the place of residence. The staff of such centers serves about 1.5 million people, including about 400 thousand disabled people of various categories. One social worker accounts for more than 10 people in cities, and more than 6 in villages (Social protection in Ukraine, stat. digest, 2018).

Such statistics is rather disappointing against the background of the dynamic growth of the ageing rate of the Ukrainian nation, the number of persons with disabilities (according to statistical data: 2568.5 thousand people in 2015, 2614.1 thousand people in 2016, 2603.3 thousand people in 2017 and 2635.6 thousand people in 2018) and insufficient level of the Human Development Index. Concerning the latter, it should be noted that in 2017, Ukraine reached a level of 0.751 , which is below the average for countries in the group with a high Human Development Index, which is 0.757 , and below the average for Europe and Central Asia, is 0.771.

Another important indicator characterizing the standard of living is employment. During the first 9 months of 2018, according to official data released by the State Employment Service of Ukraine, the number of unemployed in Ukraine amounted to 1,549.3 thousand people, of which $33 \%$ (503.9 thousand people) live in rural areas. The unemployment rate (according to the methodology of the International Labour Organization) in rural areas was $9.0 \%$ of the economically active population (Ukraine: The World Factbook, 2019). As of January 1, 2019, 341.7 thousand people had the status of unemployed. In their composition, $46 \%$ (158.5 thousand people) are rural residents. For comparison, Poland is significantly more employed in the agrarian sector - $11.5 \%$ (2015) (Poland : The World Factbook, 2019) versus $5.8 \%$ (2014) in Ukraine.

In addition, in Ukraine in 2018, the population aged 55 years and older was about $30.5 \%$, and in the structure of the rural population, this index is significantly higher. According to the national demographic forecast, by 2025 the proportion of people over 60 in Ukraine will be $25 \%$ of the total population aged 65 and older - $18.4 \%$, and in 2030 - more than $26 \%$ and more than $20 \%$, respectively (Strategy of state policy in relation to the healthy and active age of the population until 2022, 2018).

This indicates the presence of objective reasons justifying the need to study possible ways to increase the employment of the rural population of Ukraine. And the most important of them is overcoming unemployment and solving a number of social issues. 
However, it is the situation related to the availability of vacant labour that can play a positive role in the development of care institutions in rural areas. The Ukrainian mentality, developed historically, is to foster respect for parents, and therefore most of the elderly care for children. In addition, traditionally by occupational groups in recent years, there has been the least amount of vacancies for skilled workers in agriculture and forestry, fish farming and fisheries. Therefore, internal and international migration among agricultural workers is a common phenomenon in Ukraine. It should be stated that the rural population, in spite of the significant level of unemployment, is not very willing to migrate. Therefore, the implementation of measures, aimed at the development of care facilities, could solve another issue - the issue of the rural population employment.

In general, there are many different factors that influence the development of a network of care institutions. These are norms, and the level of resource capabilities, and the state of development of the accounting system, which provides official data for statistical bodies, etc. In addition, the level of informing on the development of care institutions and focus on this sector should be considered as an important factor. The results of the survey of heads of united territorial communities (UTC), carried out within the framework of the decentralization program in Ukraine (Figure 1), indicate the following problems related to informing.

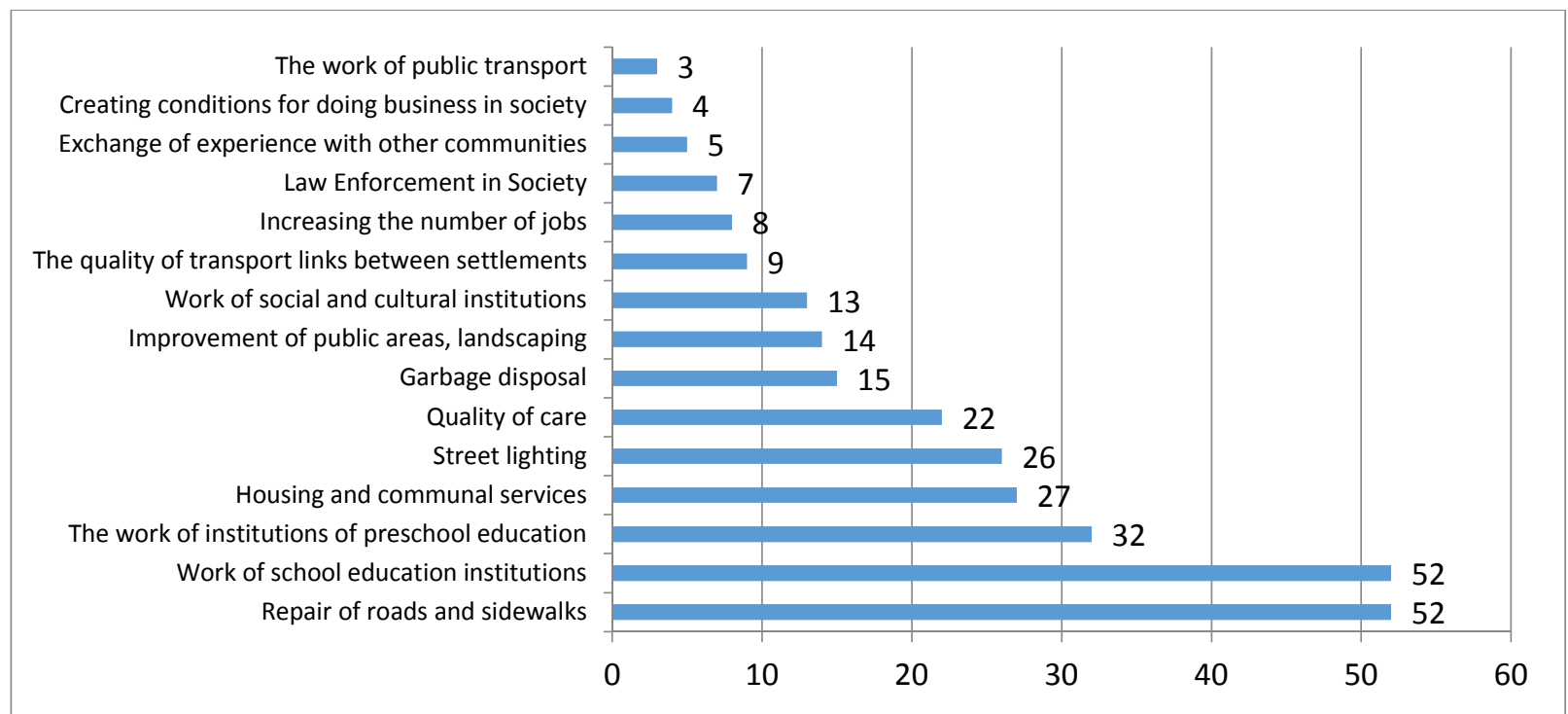

Source: Report on the research findings on the progress in territorial communities' unification. Ukraine July 2017. Available at https://decentralization.gov.ua/pics/upload/431-1c8bc38da67e046310412ce0524d2485.pdf

Fig. 1 Strategic directions of the community development (opinion of the leadership of the united territorial communities)

As can be seen from Figure 1, among the questions in the questionnaire, there is No question on social protection and organization of care for the elderly and disabled. Only 13 out of 52 respondents (which is about $24.5 \%$ ) consider the work of social and cultural institutions to be a priority for the development of a united territorial community.

But the results of a survey among students of economic specialities of universities in Ternopil and Kamianets-Podilskyi on their position on the areas of spending budget funds show the following result (out of 150 respondents): $63 \%$ consider priority spending on supporting business development, education and science, health care and social protection (including the development of military rehabilitation centres and care centres for the elderly and disabled) $23 \%$ - defence, youth housing programs, transport communication service; $10 \%$ - development of the united territorial communities, energy-saving technologies and agriculture; $4 \%$ - overcoming unemployment, the environment, public administration. The list of possible ways of spending budget funds, in addition 
to the above mentioned, also includes culture and art, foreign economic activity, and reform of state institutions.

According to a survey of 150 people aged over 80 years living in rural areas, the following results were obtained (Table 1 ).

Results of a survey of elderly people aged 80 years * (150 people surveyed)

\begin{tabular}{|l|c|c|c|}
\hline \multicolumn{1}{|c|}{ Questions } & Answer & Amount & $\begin{array}{c}\text { \% of the total number } \\
\text { of respondents }\end{array}$ \\
\hline Do you live yourself? & yes & 102 & 68.0 \\
\hline Do you have a carer from a social welfare body? & yes & 18 & 12.0 \\
\hline Are you satisfied with the level of care for you? & yes & 39 & 26.0 \\
\hline Do you need constant care? & yes & 32 & 21.3 \\
\hline $\begin{array}{l}\text { Do children take care of you more than once a } \\
\text { week? }\end{array}$ & yes & 27 & 18.0 \\
\hline $\begin{array}{l}\text { Do you consider it necessary to form care } \\
\text { institutions in your area if you are not able to } \\
\text { receive home care? }\end{array}$ & yes & 128 & 85.3 \\
\hline $\begin{array}{l}\text { Do you think that caregivers can provide more } \\
\text { qualified services than family and friends? }\end{array}$ & yes & 137 & 91.3 \\
\hline $\begin{array}{l}\text { Are care services sufficiently developed in your } \\
\text { area? }\end{array}$ & yes & 12 & 8.0 \\
\hline
\end{tabular}

* Ternopil and Kamianets-Podilskyi region, Ukraine

We suppose that such survey results indirectly indicate the need for the development of care institutions for the elderly and disabled people. Thence one can make an objective conclusion on the expediency of expanding the Ukrainian market of services through the creation of private boarding houses for the elderly and disabled, where the medical and social care of high-level would be provided.

Taking into account the favourable conditions for the implementation of such activities in rural areas, we tend to think about the good prospects for the establishment of geriatric institutions based on the principles of private property. Regarding the legislative regulation point of view, issues of social protection of the elderly in Ukraine are regulated by standards of different levels (Table 2 ).

Basic legal and regulatory acts and their provisions on the organization of services and care for the elderly and disabled in Ukraine

\begin{tabular}{|l|l|}
\hline \multicolumn{1}{|c|}{ Legal act } & \multicolumn{1}{c|}{ Content of recommendations } \\
\hline $\begin{array}{l}\text { The Law of Ukraine "On the } \\
\text { Basic Principles of Social } \\
\text { Protection of Labour Veterans } \\
\text { and Other Elderly Citizens in } \\
\text { Ukraine"* }\end{array}$ & $\begin{array}{l}\text { Article } 32 \text { guarantees senior citizens free medical care in geriatric } \\
\text { centres, hospitals for elderly citizens and other inpatients, outpatient } \\
\text { clinics, as well as at home, taking into account the achievements of } \\
\text { gerontology and geriatrics in the manner prescribed by the legislation of } \\
\text { Ukraine on health care. } \\
\text { Article } 36 \text { states that "social assistance to senior citizens who have } \\
\text { partially or completely lost the ability to self-care, at their request, can } \\
\text { be care provided directly at home or in an appropriate institution } \\
\text { (orphanage, territorial social service centre, home for veterans, boarding } \\
\text { house for aged citizens or in another institution) temporarily or } \\
\text { permanently ". }\end{array}$ \\
\hline $\begin{array}{l}\text { Order of the Ministry of Social } \\
\text { Policy "On approval of model } \\
\text { regulations on residential } \\
\text { homes (boarding houses) for } \\
\text { the elderly and disabled"** }\end{array}$ & \begin{tabular}{l} 
Regulates the activities of boarding houses \\
\hline
\end{tabular}
\end{tabular}

* Source : Legislation of Ukraine. Order of the Ministry of Social Policy "On approval of model regulations on residential homes (boarding houses) for the elderly and disabled". Retrieved from https://zakon.rada.gov.ua/laws/show/3721-12

* Source : Legislation of Ukraine. Order of the Ministry of Social Policy "On approval of model regulations on residential homes (boarding houses) for the elderly and disabled" Retrieved from

https://zakon.rada.gov.ua/laws/show/z0066-02?lang=en 
The legal and regulatory documents listed in Table 2 contain key and fundamental regulations, compliance with which guarantees care at the proper level. This regulation is strengthened by the accession of Ukraine to international agreements on the organization of care for the elderly and disabled.

Despite this, one of the major problems in improving the quality of care and development of these institutions is the lack of leverage over the activities of private care institutions. They began to develop over the past 15 years. However, their records are still not kept. Accordingly, there are No effective influence and control leverage over their activities. Residence in such establishments is paid by relatives or persons in need of care. Most private establishments have comfortable living conditions and high-quality care. However, there are also examples of accidents, including fires, in which were injured. Therefore, there is a need to develop controlling institutions, as well as to improve the accounting system of business entities of private ownership and the activities they carry out.

The initial condition for the development of care institutions in rural areas, as already noted, is the availability of the able-bodied population. However, the dynamics of this indicator for 2014-2017 has a negative tendency to decrease in the number of persons of working age (from 16 to 59 years old.) (Table 3).

Table 3

Resident population* (as for 1 January; thousands persons)

\begin{tabular}{|c|c|c|c|c|c|}
\hline & 2014 & 2015 & 2016 & 2017 & 2018 \\
\hline Total & 45245.9 & 42759.7 & 42590.9 & 42414.9 & 42216.8 \\
\hline $\begin{array}{l}\text { including: } \\
\text { male } \\
\text { female }\end{array}$ & $\begin{array}{l}20918.3 \\
24327.6\end{array}$ & $\begin{array}{l}19787.8 \\
22971.9\end{array}$ & $\begin{array}{l}19717.9 \\
22873.0\end{array}$ & $\begin{array}{l}19644.6 \\
22770.3\end{array}$ & $\begin{array}{l}19558.2 \\
22658.6\end{array}$ \\
\hline Rural population & 14164.9 & 13325.3 & 13244.7 & 13171.4 & 13084.6 \\
\hline $\begin{array}{l}\text { including: } \\
\text { male } \\
\text { female }\end{array}$ & $\begin{array}{l}6673.9 \\
7491.0\end{array}$ & $\begin{array}{l}6284.7 \\
7040.6\end{array}$ & $\begin{array}{l}6254.2 \\
6990.5\end{array}$ & $\begin{array}{l}6225.9 \\
6945.5\end{array}$ & $\begin{array}{l}6194.4 \\
6890.2\end{array}$ \\
\hline Share of rural population, $\%$ & 31.3 & 31.2 & 31.1 & 31.1 & 31.0 \\
\hline $\begin{array}{l}\text { including: } \\
\text { male } \\
\text { female }\end{array}$ & $\begin{array}{l}31.9 \\
30.8\end{array}$ & $\begin{array}{l}31.8 \\
30.6\end{array}$ & $\begin{array}{l}31.7 \\
30.6\end{array}$ & $\begin{array}{l}31.7 \\
30.5\end{array}$ & $\begin{array}{l}31.7 \\
30.4\end{array}$ \\
\hline Population at the age $16-59$ & 28372.5 & 26613.3 & 26317.4 & 25982.0 & 25641.3 \\
\hline $\begin{array}{l}\text { including: } \\
\text { male } \\
\text { female }\end{array}$ & $\begin{array}{l}13796.8 \\
14575.7\end{array}$ & $\begin{array}{l}12962.7 \\
13650.6\end{array}$ & $\begin{array}{l}12834.3 \\
13483.1\end{array}$ & $\begin{array}{l}12689.6 \\
13292.4\end{array}$ & $\begin{array}{l}12541.2 \\
13100.1\end{array}$ \\
\hline Rural population at the age $16-59$ & 8442.1 & 7911.9 & 7855.4 & 7792.1 & 7707.6 \\
\hline $\begin{array}{l}\text { including: } \\
\text { male } \\
\text { female }\end{array}$ & $\begin{array}{l}4271.7 \\
4170.4\end{array}$ & $\begin{array}{l}4007.0 \\
3904.9\end{array}$ & $\begin{array}{l}3977.8 \\
3877.6\end{array}$ & $\begin{array}{l}3945.2 \\
3846.9\end{array}$ & $\begin{array}{l}3905.4 \\
3802.2\end{array}$ \\
\hline $\begin{array}{l}\text { Share of rural population at the age 16- } \\
59, \%\end{array}$ & 29.8 & 29.7 & 29.8 & 30.0 & 30.0 \\
\hline $\begin{array}{l}\text { including: } \\
\text { male } \\
\text { female }\end{array}$ & $\begin{array}{l}31.0 \\
28.6\end{array}$ & $\begin{array}{l}30.9 \\
28.6\end{array}$ & $\begin{array}{l}31.0 \\
28.8\end{array}$ & $\begin{array}{l}31.1 \\
289\end{array}$ & $\begin{array}{l}31.1 \\
29.0\end{array}$ \\
\hline
\end{tabular}

* Excluding the temporarily occupied territories of the Autonomous Republic of Crimea, and the city of Sevastopol.

Source: Agriculture of Ukraine - 2017. Statistical Yearbook (2018). Kyiv: State Statistics Service of Ukraine, p. 19

From table 3 it can be seen that the rural population at the age 16-59 in 2014 numbered 8442.1 thousand people, and in 2017 by 734.5 thousand people less ( 7707.6 thousand people). According to the implementation structure through 2014-2017, mail population prevails and this is a steady trend (the index ranges from 30.9 to $31.1 \%$ ). 
The employed population in 2017 numbered 16156.4 thousand people (Table 4), which constitutes $38.27 \%$ of the total population of Ukraine. The number of employed persons in the rural population in 2017 amounted to 2,860.7 thousand people, which is more than $37.1 \%$ of the rural population aged $16-59$, or $21.86 \%$ of the total rural population.

Table 4

\section{Employment by type of economic activity * (thousands persons / percentage} to total)

\begin{tabular}{|c|c|c|c|c|c|c|c|c|}
\hline & \multicolumn{2}{|c|}{2014} & \multicolumn{2}{|c|}{2015} & \multicolumn{2}{|c|}{2016} & \multicolumn{2}{|c|}{2017} \\
\hline Total & 18073.3 & 100 & 16443.2 & 100 & 16276.9 & 100 & 16156.4 & 100 \\
\hline $\begin{array}{l}\text { Agriculture, forestry and } \\
\text { fishing }\end{array}$ & 3091.4 & 17.1 & 2870.6 & 17.5 & 2866.5 & 17.6 & 2860.7 & 17.7 \\
\hline Industry & 2898.2 & 16.1 & 2573.9 & 15.7 & 2494.8 & 15.3 & 2440.6 & 15.1 \\
\hline Constructions & 746.4 & 4.1 & 642.1 & 3.9 & 644.5 & 4.0 & 644.3 & 4.0 \\
\hline $\begin{array}{l}\text { Wholesale and retail trade; } \\
\text { repair of motor vehicles, } \\
\text { motorcycles }\end{array}$ & 3965.7 & 21.9 & 3510.7 & 21.3 & 3516.2 & 21.6 & 3525.8 & 21.8 \\
\hline $\begin{array}{l}\text { Transportation and storage, } \\
\text { postal and courier activities }\end{array}$ & 1113.4 & 6.2 & 998.0 & 6.1 & 997.2 & 6.1 & 991.6 & 6.1 \\
\hline $\begin{array}{l}\text { Accommodation and food } \\
\text { service activities }\end{array}$ & 309.1 & 1.7 & 277.3 & 1.7 & 276.7 & 1.7 & 276.3 & 1.7 \\
\hline $\begin{array}{l}\text { Other types of economic } \\
\text { activity }\end{array}$ & 5949.1 & 32.9 & 5570.6 & 33.8 & 5481.0 & 33.7 & 5417.1 & 33.6 \\
\hline
\end{tabular}

In the number of the permanent rural population, the number of persons under the age of 15 is 2329.4 thousand. Thus, there is a reason to assert that, from the point of view of providing labour resources, now and in the long run rural areas have significant reserves. This should be assessed as a positive factor in the organization of activities for the care of the elderly and disabled people. However, the delay in improving the legislative framework and the creation of favourable conditions for the development of both state institutions and private care institutions may lead to the loss of a significant amount of labour resources through the international migration of the Ukrainian population. Therefore, the existing advantages of the working population availability should be immediately taken.

Another important condition for the development of care institutions is the material and technical base. The presence of free premises in the rural area (state ownership and premises belonging to territorial communities) can be positively assessed. These are the premises of former kindergartens, hospitals that are in good condition. They were freed due to the reform and consolidation of health care facilities and due to the reduced need for the number of places in kindergartens due to the decline in the birth rate in Ukraine. In particular, according to statistical data, the number of hospitals in Ukraine in 2015 calculated 1,775 units, in 2016 - 1,743 units, and in 2017 - 1,714 units (Health Care institutions and the incidence of the population of Ukraine in 2017. Statistical digest, 2018). That is, in 3 years the number of hospitals decreased by 61 units. Such premises are the most adapted to the residence of persons in need of care. Subject to their refurbishment and major repairs, these facilities can serve a good material basis for care activities. Construction of new buildings will cost much more. Though, it is not a significant obstacle to the development of such a needed and demanded activity.

An alternative approach to care also includes a home wardship. In Ukraine, it develops within the framework of the All-Ukrainian social program "Home care". Such care is exercised over single people who cannot take care of themselves on their own. Actually, the provision of high-quality medical and 
social assistance to those in need is guaranteed thanks to the approval of the program. This line of assistance was established in Ukraine in 1998. However, in case of both, the care institutions and in the organization of home care, there is one and the same problem - the provision of qualified personnel. Nowadays, there are practically No institutions, training specialists for nursing the elderly and disabled people in Ukraine. This problem should also be solved soon.

\section{Conclusions, proposals, recommendations}

The conducted study allows concluding that there is an objective need and favourable conditions for the development of care activity for the elderly and the disabled in rural areas of Ukraine. There is also a number of issues and obstacles to be solved in order to enhance care services. A number of measures should be taken to ensure the dynamic development of the institutions' network and care activities.

To improve the quality of care, it is advisable to develop and approve national standards for care, which should be based on international requirements, including Minimum standards for the inclusion of the elderly and disabled in humanitarian response programs (Age and Disability Consortium, 2015).

Private institutions establishment will positively affect the scope of care services. However, a prerequisite for such activities should be a license. The public institution, namely the above mentioned State Service for the Care Services Quality, should be entrusted with the issuance of such a license. In addition, it is necessary to establish a system for monitoring and assessing the quality of the services provided by state and public regulatory bodies. One of the most effective levers over care activity should become the development of the system of informing on the inspections results.

To improve the accounting of business entities, providing care services of private ownership, and the activities they carry out, it is necessary:

- to create a Unified Register of social service providers and to introduce mandatory registration of care providers in it;

- to develop a system of standards for cost per capita, which is being watched, as well as an approach to the formation of individual cost calculations. This is due to the individual and specific needs of each person (state of health, the need for medicine and care products, the individual characteristics of the body, etc.).

In order to attract the rural working-age population to the provision of care services, retraining courses with the issuance of a relevant certificate, and training programs for care specialist in medical education institutions should be established. The development of volunteering (conducting training sessions with older people in different specialities, for example, mastering computers) is quite perspective.

\section{Bibliography}

1. Agriculture of Ukraine - 2017. Statistical Yearbook (2018). Kyiv: State Statistics Service of Ukraine, 245 p.

2. Arai, H., Ouchi, Y., Yokode, M., Ito, H., Uematsu, H., Eto, F., ... Members of the Subcommittee for Aging. (2012). Toward the realization of a better aged society: Messages from gerontology and geriatrics. Geriatrics \& Gerontology International, 12, 16-22. doi:10.1111/j.1447-0594.2011.00776.x.

3. Artz, B., Davis, D.B. (2017). Green Care: A Review of the Benefits and Potential of Animal-Assisted Care Farming Globally and in Rural America. Animals, 7(4), 31. doi:10.3390/ani7040031

4. Berezin, O.V., Bezpartochniy, M.G. \& Nikileva, L.O. (2013). Mekhanizmy formuvannya ta metodolohiya rozvytku zakladiv i pidpryyemstv sotsial'noho obsluhovuvannya (The mechanisms of formation and methodology development institutions and enterprises of social services). Poltava: InterGrafic

5. Bookman, A., \& Kimbrel, D. (2011). Families and Elder Care in the Twenty-First Century. Future of Children, 21(2), 117-140. 
6. Chaikovskaya, V. Home care in Ukraine: how and to whom is social assistance provided for singles? Press Center "Glavkom". Retrievied from https://glavcom.ua/specprojects/press_center/domashnya-opika-vukrajini-yak-i-komu-nadajetsya-socialna-dopomoga-dlya-samotnih-441467.html

7. Chopenko, V.M. (2014) Shliakhy podolannia sotsialno-demohrafichnoi kryzy na seli (Ways of overcoming the socio-demographic crisis in the countryside). Ekonomika APK, 11, 56-60.

8. Davydiuk, O.O. (2016). Deinstytutsionalizatsiia sotsialnoho obsluhovuvannia osib pokhyloho viku $v$ Ukraini. Demohrafiia ta sotsialna ekonomika, Vol. 2, Issue 27, pp. 143-155.

9. Kaminski, R., Marcysiak, T., \& Prus, P. (May 9-11, 2018). The Development of green Care in Poland. In: Proceedings of the 2018 International Conference «ECONOMIC SCIENCE FOR RURAL DEVELOPMENT», No 49, Jelgava, LLU ESAF, pp. 307-315. DOI 10.22616/ESRD.2018.148 1.

10. Kaniuk, O. (2015). Profesiini vymohy do maibutnikh sotsialnykh pratsivnykiv (Professional requirements for future social workers). Aktualni pytannia humanitarnykh nauk, No 11, pp. 252-259.

11. Mazura, I. (2012). Problema starinnia natsii dobralasia i do Ukrainy? Informahentsvo Forum (The problem of aging of the nation got to Ukraine? Information Agency Forum). Retrieved: https://forua.com/analytics/2012/04/18/083044.html

12. Minimalni standarty vkliuchennia osib pokhyloho viku ta liudei $z$ invalidnistiu (Minimum standards include older people and people with disabilities). (ADCAP). Age and Disability Consortium. 2015. Retrieved: https://www.humanitarianresponse.info/sites/www.humanitarianresponse.info/files/documents/files/minimu m_standards_ukrainian.pdf

13. Poland : The World Factbook (2019). Washington, D.C. : Central Intelligence Agency. Retrieved: https://www.cia.gov/library/publications/the-world-factbook/geos/pl.html.

14. Semygina, T., \& Gryga, I. (Eds.) (2004). Social'na robota z konkretnymy grupamy klijentiv (Social work with specific groups of clients). Kyiv: Kyievo-Mogyljanska Akademija.

15. Social protection in Ukraine, stat. digest. (2018). State Statistics Office of Ukraine. Retrieved: http://www.ukrstat.gov.ua/druk/publicat/kat_u/2018/zb/07/zb_szn_2017.pdf.

16. Schuringa, L. (April 2018). The transition from Green to Yellow How to really make it happen. Utrecht, 16 p.

17. Semyhina, T.V. (2007). Orhanizatsiya nadannya sotsial'nykh posluh na rivni hromady yak zahal'na tendentsiya rozvytku sotsial'noyi roboty (The organization of social services at the community level as a general trend of social work). Sotsial'na polityka, sotsial'na robota y okhorona zdorov'ya: yak Ukrayini dosyahty yevropeys'koho rivnya yakosti posluh? (Proceeding conference «Social policy, social work and health, as Ukraine reach the European level of service quality?»), pp. 35-38. Kyiv: Sphera.

18. Stratehiia derzhavnoi polityky z pytan zdorovoho ta aktyvnoho dovholittia naselennia na period do 2022 roku: Rozporiadzhennia Kabinetu Ministriv Ukrainy vid 11.01.2018 r. № 10-r. (Strategy of state policy in relation to the healthy and active age of the population until 2022) (2018). Retrieved: http://gl.kradmin.gov.ua/index.php/blog/item/1138-stratehiia-derzhavnoi-polityky-z-pytan-zdorovoho-ta-aktyvnohodovholittia-naselennia-na-period-do-2022-roku

19.Zaklady okhorony zdorovia ta zakhvoriuvanist naselennia Ukrainy u 2017 r. Statystychnyi zbirnyk (Health Care institutions and the incidence of the population of Ukraine in 2017. Statistical digest). Kyiv: Derzhavna sluzhba statystyky Ukrainy, 2018. 109 p.

20.Zvit pro rezultaty doslidzhennia uspishnosti obiednannia terytorialnykh hromad. Ukraina. Lypen 2017 r. (Report on the research findings on the progress in territorial communities unification. Ukraine. (July 2017). Retrieved: https://decentralization.gov.ua/pics/upload/431-1c8bc38da67e046310412ce0524d2485.pdf

21.Ukraine: The World Factbook (2019). Washington, D.C.: Central Intelligence Agency. Retrieved https://www.cia.gov/library/publications/the-world-factbook/geos/up.html.

22. Vitchyznianyi ta zarubizhnyi dosvid orhanizatsii dozvillia liudei pokhyloho viku (Domestic and foreign experience in organizing the leisure of the elderly) (January 31, 2018). Osvita.ua. Retrieved: http://osvita.ua/vnz/reports/culture/11085/. 